\title{
Early Holocene human occupation and environment of the southeast Australian Alps: New evidence from the Yarrangobilly Plateau, New South Wales
}

\author{
Ken Aplin \\ Australian National Wildlife Collection, CSIRO Division of Sustainable Ecosystems, Canberra, Australia \\ Ken.Aplin@csiro.au
}

\section{Fred Ford}

Australian National Wildlife Collection, CSIRO Division of Sustainable Ecosystems, Canberra, Australia

\section{Peter Hiscock}

School of Archaeology and Anthropology, Australian National University, ACT, Australia

\section{Introduction}

The sciences of Quaternary studies and archaeology have developed hand in hand in Australasia so that, as a rule, there is a close match for any particular biome between knowledge of lateQuaternary environments and both the time depth and richness of regional archaeological records. The southeast Australian Alps represent a significant exception to this rule. For while the environmental history of this biome is relatively well known, at least since the termination of the last glaciation at c. 16,000 BP (e.g. Kershaw and Strickland 1989; Martin 1999; Barrows et al. 2001; Hope 2003; Kershaw et al. 2007), evidence of human activity above 1000 m elevation currently extends back no further than 4000 years (Flood 1980; Kamminga 1992, 1995; Lourandos 1997; Mulvaney and Kamminga 1999). Even more remarkably, the regional palaeoenvironmental record does not contain a strong signature of prehistoric human activity. For example, Geoffrey Hope's extensive palynological and sedimentological studies of mountain mires in New South Wales and the ACT found no obvious signature of prehistoric burning that might be linked to human activity (Macphail and Hope 1985; Hope 2003), a result that is replicated elsewhere in the region (Ladd 1979; Green et al. 1988; Kershaw and Strickland 1989; Dodson et al. 1994; McKenzie 1997, 2002; Mooney et al. 1997). In contrast, many sites show a marked increase in charcoal associated with the appearance of Pinus pollen, 
marking the onset of European land management practices (Hope 2003). Indeed, as Hope (2003:74) remarked, 'The impact of European pastoralism ... is the greatest alteration to the environment that can be seen in the Holocene.'

Extensive archaeological survey of the southeast Australian Alps by Josephine Flood in the 1970s failed to locate any sites older than 4000 years in the wider region, and only very sparse lithic scatters at elevations above $1200 \mathrm{~m}$ asl (Flood 1980). Further survey work in the 1980s and '90s (Kamminga 1992, 1995) failed to alter this situation; at present, the earliest evidence of occupation above $1000 \mathrm{~m}$ asl is dated to c. $4000 \mathrm{cal}$ BP at Nursery Swamp (1140 $\mathrm{m}$ asl) in the ACT (Flood et al. 1987). In contrast, there is evidence of considerably earlier occupation from various localities around the margin of the southeastern Australian Alps, including Cloggs Cave at $76 \mathrm{~m}$ asl in East Gippsland, where evidence of human occupation extends back to c. 21,000 cal BP (Flood 1980), and Birrigai in the ACT at $730 \mathrm{~m}$ asl, with a basal occupation date of c. 25,000 cal BP (Flood et al. 1987). A question of considerable interest in this regional context concerns the antiquity of the ethnographically documented seasonal exploitation of bogong moths, a food resource rich in protein and fat that is available during the summer months at high-elevation aestivation sites (Flood 1980).

The enigma of the apparently late aboriginal occupation of the southeast Australian Alps, and its seemingly gentle footprint, is given additional emphasis by the documentation over the past two decades (Kiernan et al. 1983; Jones 1995; Cosgrove 1999) of human occupation of river valleys on the western margin of the central plateau of Tasmania throughout the period of the Last Glacial Maximum (LGM; c. 26,000-16,000 BP; Barrows et al. 2001), involving exploitation of a subalpine landscape featuring a mosaic of low tree heaths, sedgelands, grasslands and herbfields (Colhoun and van de Geer 1986, 1994; Cosgrove et al. 1990). This occupation started around 31,000 BP and continued until termination of glacial conditions, when the region became densely forested. If people were so successfully exploiting subalpine and even alpine environments in Tasmania through the LGM, it seems reasonable to expect that they were at least technologically equipped to exploit a large area of broadly similar biomes in the southeast Australian Alps, located a relatively short distance north across the exposed Bassian Plain.

Here we report new evidence for early Holocene human activity in the southeast Australian Alps, derived from a shallow test excavation in cave Y259, located at $1100 \mathrm{~m}$ asl near the Yarrangobilly Caves, New South Wales (Figure 1). We also present our preliminary observations of a rich, associated non-cultural mammalian fauna that allows inferences to be drawn regarding local environmental conditions during and after the period of human occupation of the site.

\section{Site Y259}

Y259 in the Australian Speleological Federation Karst Index Database (http://www.caves. org.au/kid/) is located in a doline on what is informally known as the plateau area of the Yarrangobilly karst. The doline is around $1100 \mathrm{~m}$ asl and lies at the intersection of two bioregions (Thackway and Creswell 1995): the Australian Alps and the southeast Highlands (the latter represented by the Bago subregion) (see Figure 1). The doline has a maximum cliff height of around $20 \mathrm{~m}$, but more subdued relief at the northern end allows straightforward pedestrian access. The vegetation in the doline and immediate surrounds is open snowgum (Eucalyptus pauciflora subsp. pauciflora) and black sallee (E. stelullata) woodland with a snowgrass (Poa sieberi) dominated understorey. This open vegetation continues along a vague drainage line trending westwards across the top of the gently sloping plateau of the Yarrangobilly Limestone until reaching the steep gorge of the Yarrangobilly River, which has very open vegetation on rocky slopes. Steeper slopes of sediments of the Ravine Beds and Gooborrangandra Porphyry 


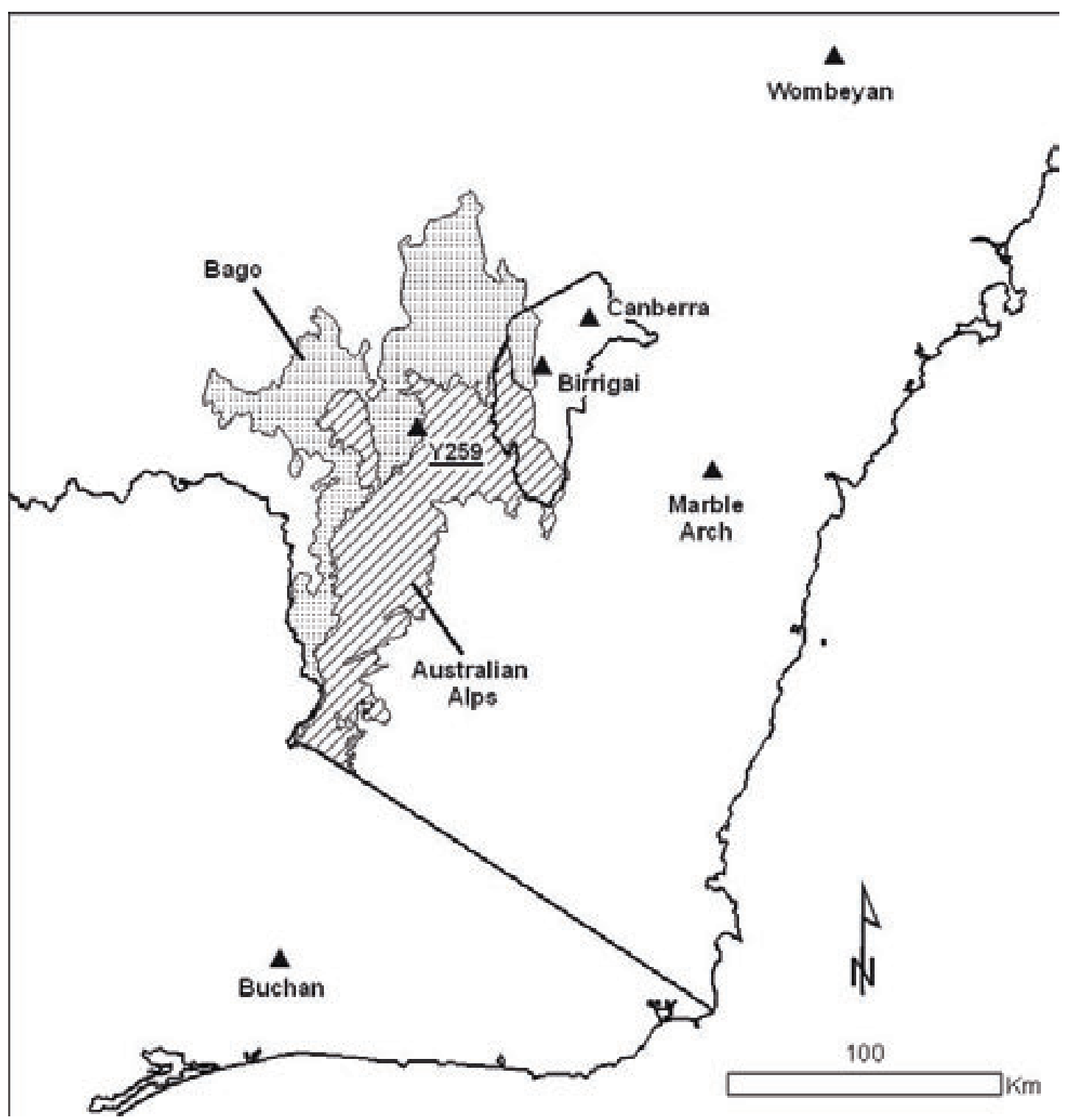

Figure 1. Map of southeastern Australia showing the boundaries (for New South Wales only) of the Bago sub-bioregion (Southeast Highlands bioregion) and the Australian Alps bioregion of the Interim Biogeographic Regionalisation of Australia (IBRA; Thackway and (reswell 1995), and the location of various archaeological and palaeontological localities mentioned in the text. Site Y259 is located almost exactly on the boundary between the two IBRA regions. The location of Buchan includes both Cloggs Cave and Pyramids Cave

immediately to the east and north of the doline possess denser montane open forests dominated by mountain gum (E. dalrympleana) and narrow-leafed peppermint (E. robertsonii), with ribbon gum (E. viminalis) along creek lines, and scattered individuals and small stands of alpine ash (E. delegatensis). An open midstorey of blackwood (Acacia melanoxylon) and silver wattle (A. dealbata) and an open shrubby understorey of mat rush (Lomandra spp.), bracken (Pteridium esculentum) and beard heath (Leucopogon hookeri) covers most of these slopes.

Y259 is essentially a cleft situated between the doline wall (which forms its western wall) and several massive, detached blocks that form both its eastern wall and a partial roof. The floor area is approximately $15 \mathrm{~m}$ by $5 \mathrm{~m}$, with its long axis orientated approximately northsouth (Figure 2). The northern end of the cleft is entered via a short descent from the floor of the doline; this area is well-lit and largely open to the elements. The southern end of the cleft is more confined and sheltered, with a low roof along the eastern side and a high but narrow cleft leading to an elevated opening on the western side. Active cave formation is present on the sloping western wall and on the lower roof at the southern end. 


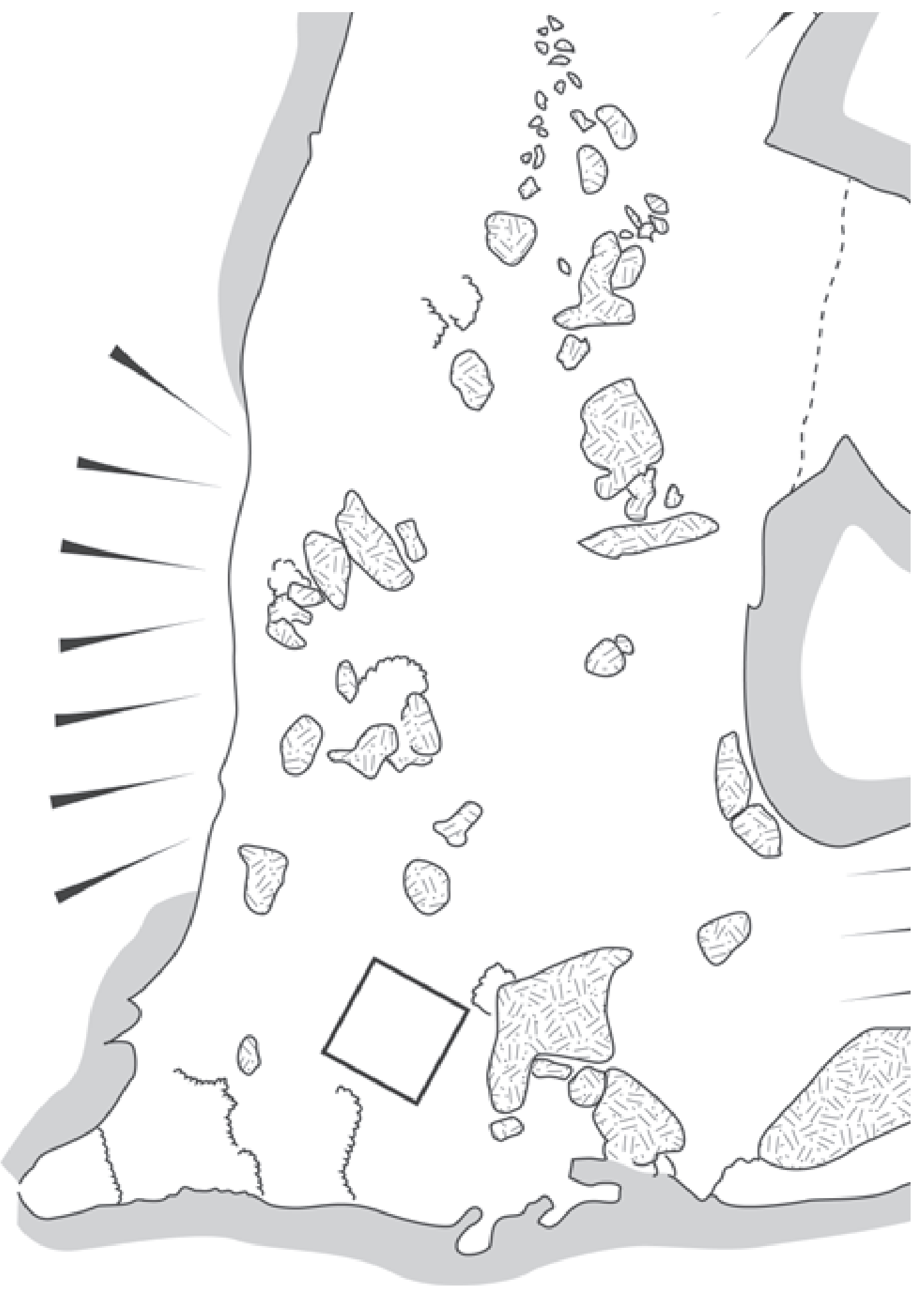

Figure 2. Floor plan of Y259. The position of the test excavation is indicated. Arrows indicate the slope down from the three external openings of the cave

The cave deposit comprises a sub-horizontal accumulation of fine, in-washed sediments bedded around scattered pieces of roof fall. Sediment probably enters at both ends of the cave and the surface slopes down to a low point located in the centre on the eastern side; this area of the cave floor is prone to inundation. Elsewhere, the surface is damp and supports a thin layer of mosses wherever light penetrates to the cave floor. In the darker reaches, the surface bears a powdery white 'frosting' of calcium carbonate. Dissociated small vertebrate bone is 
scattered over much of the floor surface but is concentrated at both ends of the cleft, where shelves suitable for roosting owls are present several metres above the floor.

Numerous remains of bogong moths were noted in the cave at the time of excavation and on other visits, and these identify Y259 as a minor aestivation site. The site is much lower than most known aestivation sites, which tend to be found higher than $1400 \mathrm{~m}$ asl (Mansergh et al. 1990; Broome 2001), but these are generally boulder-strewn sites that lack the depth or coolness of limestone caves. Y259 is probably subject to more significant diurnal temperature variations than many other local caverns that lack moths due to its open roof and small size. Cold overnight temperatures might benefit aestivating moths when compared with more stable climates in other caves, while daytime temperatures are still cool due to the massive limestone roof.

Drummond (1963) performed an excavation in Y259 (reported as Y50, which occupies the same doline; Andy Spate of the Canberra Speleological Society indicated the location of Drummond's excavation to us) and reported that 'many thousands of bones' were collected (p. 35). He recorded 14 species of mammal in two samples: 375 identifiable bones from the 'Surface' and 136 bones from 'Layer 3 Down' (Drummond 1963:40) and made some remarks about the significance of differences in faunal composition between the two reported layers. The whereabouts of Drummond's collection is not known.

\section{The test excavation}

Our excavation in Y259 was undertaken as part of a regional survey of the 'original' (i.e. late prehistoric to early historic) mammalian fauna of the southeast Australian Alps and adjacent Southern Tableland regions. This work is primarily focussed on bone deposits accumulated by non-human predators, many of which are in small caverns unsuitable for human occupation and with little or no sediment accumulation. However, a few larger cave sites, including Y259, have prey remains incorporated into deeper sediment accumulations. These provide opportunities for recovering faunal samples from stratified and potentially dateable contexts.

A $1 \mathrm{~m}^{2}$ test pit was positioned at the southern end of the floor area of Y259 (shown on Figure 2), in an area that contained the highest density of surface bone, the minimal amount of surface limestone rubble, and an absence of obvious recent surface wash. Loose material to a depth of approximately $1 \mathrm{~cm}$ was brushed up as a 'Surface' sample, hereafter termed 'Spit $S$ '. Subsequent excavation was carried out by visible stratification, or approximately $2 \mathrm{~cm}$ spits, when sediment appeared homogenous. On completion of Spit 6, a flowstone-capping brecciated sediment was encountered. The flowstone was breached only over the eastern half of the square and excavation continued for three more spits. Charcoal samples for C14 dating were collected from each spit.

\section{Post-excavation treatment}

All excavated sediment was bagged and transported to the laboratory without sieving or other treatment. Before the main treatment, a subsample of the brecciated deposit from Spit 9 was washed, dried and examined. The presence of burnt bone and stone artefacts, not observed during excavation, alerted us to the archaeological nature of the deposit. Charcoal samples from Spits 7 and 9, spanning the depth of the brecciated unit, were submitted to the Waikato Radiocarbon Dating Laboratory for age determination using Accelerator Mass Spectrometry (AMS).

Material recovered from Spits 7-9 is the primary focus of this paper. For comparisons, we also present data for the Surface, Spit 1 and Spit 5 samples, the latter representing the first of the two flowstone-sealed sedimentary units. 
The samples from Spits S, 1 and 5 were soaked in water, washed gently through a fine mesh (approximately $0.5 \mathrm{~mm}$ ), then dried. The samples from Spits 7-9 were subjected to the same treatment except that chunks of brecciated sediment were removed and placed in a weak acetic acid solution (approximately 2-5\%, depending on degree of consolidation) for dissolution of calcium carbonate. The acid-treated residue was put through three or more changes of water to flush residual acid, then air-dried. Any material that was still brecciated was subjected to a second cycle of acid treatment.

The samples from Spits 2-4 and 6, as well as one bag of deposit from Spit 7, remain unprocessed at the time of writing, as does a significant volume of Spit 1.

\section{Sorting}

All tooth-bearing elements (dentaries, maxillae and premaxillae) and isolated teeth were separated from the remaining bone. Also picked out were cranial and selected postcranial elements (all major limb bones and pedal elements) of all taxa except murids, including birds and reptiles. All burnt bone was recovered, irrespective of taxon.

The washed and dried samples from Spits S, 5 and 7-9 were sorted in entirety, while those from Spit 1 were picked over less thoroughly due to time constraints.

\section{Taxonomic determinations}

Taxonomic determinations were checked against reference specimens held by the Australian National Wildlife Collection (ANWC) and were made in the context of taxonomic reviews of several key groups, most notably the murid rodents. Whenever possible, specimens derived from localities in the southeastern Highlands were consulted in preference to material from more remote locations. We have not yet attempted to identify the small number of reptile and bird specimens.

Several marsupials and murid represented in the Y259 assemblage fall well outside their contemporary geographic ranges as currently documented. The identification of several of these taxa warrants some brief comment.

Two species of Sminthopsis are clearly represented in all samples except Spit S. Both lack lower molar entoconids but are clearly distinguishable on tooth size and the configuration of the premolar series (less crowded in the larger-toothed form). These differences correspond with those documented by Archer (1981) between southeastern Australian samples of $S$. murina (the smaller-toothed form) and S. leucopus.

The taxon listed as Antechinus sp. cf. A. flavipes is a member of what might be called the $A$. flavipes group; this broadly distributed assemblage is in need of taxonomic revision.

Dentaries and maxillae attributed to Leadbeater's possum (Gymnobelideus leadbeateri) are very similar in overall size and shape to those of the sugar glider (Petaurus breviceps), but the two are distinguishable on the basis of molar size and corresponding alveolar dimensions (Wakefield 1972b). To further confirm the species identification, additional cranial elements (squamosal, petrosal, alisphenoid and frontal bones) of small petaurids were retrieved from the bulk bone samples from Spits 5 and 7, and compared with reference specimens of both species. Cranially, G. leadbeateri differs from $P$. breviceps in having a less pneumatised glenoid and auditory region and a narrower interorbital region. Cranial elements of both taxa are readily distinguished in the $\mathrm{Y} 259$ sample.

Drummond (1963) reported Pseudomys australis from his excavation. His specimens probably belonged to the morphologically similar $P$. higginsi, which is represented by numerous well-preserved specimens in Surface and Spits 1, 5 and 7. This taxon is known as a living animal only from Tasmania, but is recorded in various subfossil and fossil assemblages from mainland southeastern Australian sites (Wakefield 1972a, b; Hope 1976; Flood 1980). The Y259 material is consistent in all respects with the Pyramids Cave sample used by Wakefield 
(1972b) in his description of the mainland subspecies Pseudomys higginsi australiensis. Ancient DNA techniques are being applied to Yarrangobilly specimens in an effort to confirm the taxonomic affinities of mainland populations of P. higginsi.

Pseudomys oralis is not known as a living animal south of Mount Royal, in the New South Wales Central Coast hinterland, but it is recorded from recent cave deposits as far south as East Gippsland (Wakefield 1972a, b). During sorting of the Y259 and other regional bone samples, we observed that specimens with the distinctive morphology of $P$. oralis fall into two distinct size classes, with other anatomical differences observable in more complete cranial fragments. We suspect that these represent two different species, probably siblings, and herein designate them as $P$. oralis A (smaller-toothed) and $P$. oralis B (larger-toothed). Attempts are currently underway to extract ancient DNA from some of the better-preserved specimens of each form to explore the taxonomic implications of this morphological dichotomy and the relationship of these taxa to mtDNA lineage diversity described from extant $P$. oralis populations (Jerry et al. 1998).

\section{Faunal quantification and analysis}

For small mammals, only teeth and tooth-bearing specimens were selected out for identification. For comparison of taxonomic composition between excavated samples, we use a total count of allocated specimens for each taxon, expressed as the Number of Individual Specimens (NISP). We used NISP values in preference to Minimum Number of Individuals (MNI) because in such a small excavated area and with highly dissociated remains, there is no reason to believe that $\mathrm{MNI}$ values are any more representative of original relative prey abundances. Moreover, their use would certainly deflate (most to unity) the relative contribution of all of the lessabundant taxa. For the larger-bodied taxa, other cranial and postcranial elements were also identified to an appropriate taxonomic level (often only to family; e.g. as a medium-sized macropodid) and these elements are included in NISP values for these taxa. NISP values for each sample are presented in Table 1.

Table 1. Taxonomic composition of the Y259 vertebrate fauna recovered from each of Spits S and Spit 1 (Unit I), Spit 5 (Unit II), and Spits 7-9 (Unit III). All values are NISP. Taxa listed as 'Indet' are identified only to the indicated taxonomic level, e.g. 'Indet Sminthopsis sp.' are determinable as Sminthopsis but could not be identified to species level (Table 1 continues on page 194)

\begin{tabular}{|l|l|l|l|l|l|l|}
\hline Taxon & Surface & Spit 1 & Spit 5 & Spit 7 & Spit 8 & Spit 9 \\
\hline Rattus fuscipes & 707 & 462 & 393 & 106 & 141 & 29 \\
\hline Rattus lutreolus & 34 & 40 & 11 & 7 & 12 & 5 \\
\hline Indet. Rattus sp. & 47 & 63 & 19 & 33 & 10 & 8 \\
\hline Mastacomys fuscus & 99 & 64 & 39 & 14 & 26 & 10 \\
\hline Pseudomys fumeus & 103 & 92 & 37 & 6 & 13 & 5 \\
\hline Pseudomys higginsi & 30 & 16 & 2 & 1 & & \\
\hline Pseudomys novaehollandiae & 1 & 8 & 3 & 5 & 1 & \\
\hline Pseudomys oralis A & 14 & 5 & 1 & 1 & 29 & \\
\hline Pseudomys oralis B & 2 & 11 & 5 & 4 & & \\
\hline Total murids & 977 & 753 & 515 & 171 & 240 & 58 \\
\hline Acrobates pygmaeus & 14 & 9 & 10 & 3 & & \\
\hline Cercartetus nanus & 22 & 33 & 33 & 5 & 1 & \\
\hline Total small possums & 36 & 42 & 43 & 8 & 1 & \\
\hline Gymnobelideus leadbeateri & 8 & 7 & 3 & & & \\
\hline Petaurus breviceps & 1 & 1 & 15 & 4 & 4 & \\
\hline
\end{tabular}




\begin{tabular}{|c|c|c|c|c|c|c|}
\hline Taxon & Surface & Spit 1 & Spit 5 & Spit 7 & Spit 8 & Spit 9 \\
\hline Total medium possums & 1 & 1 & 23 & 11 & 7 & \\
\hline Petaurus australis & 2 & & & & & \\
\hline Pseudocheirus pergerinus & 7 & 3 & 22 & 4 & 3 & \\
\hline Trichosurus sp. & 1 & & & & & \\
\hline Total large possums & 7 & 3 & 24 & 5 & 3 & \\
\hline Potorous spp. & 2 & 1 & 2 & 5 & & \\
\hline Bettongia sp. & 1 & 2 & 2 & 2 & & \\
\hline Total potoroids & 3 & 2 & 1 & 2 & 7 & 2 \\
\hline Petrogale penicillata & 4 & 3 & 4 & & & \\
\hline Indet. small macropodid & 1 & 3 & & & & \\
\hline Total small macropodids & 4 & 1 & 6 & 4 & & \\
\hline Macropus rufogriseus & 2 & & & & & \\
\hline $\begin{array}{l}\text { Indet. medium-sized } \\
\text { macropodid }\end{array}$ & 2 & & & & & \\
\hline $\begin{array}{l}\text { Total medium-sized } \\
\text { macropodids }\end{array}$ & 2 & 2 & & & & \\
\hline Perameles nasuta & 3 & 5 & 1 & & & \\
\hline Isoodon obesulus & 7 & 3 & 5 & & & \\
\hline Indet. peramelid & 4 & & & & & \\
\hline Total peramelids & 7 & 3 & 8 & 9 & 1 & \\
\hline Sminthopsis murina & 10 & 11 & 6 & 2 & 2 & 1 \\
\hline Sminthopsis leucopus & 2 & 4 & 1 & 5 & 2 & \\
\hline Indet. Sminthopsis sp. & 1 & & & & & \\
\hline Antechinus agilis & 86 & 64 & 94 & 15 & 32 & 6 \\
\hline Antechinus swainsonii & 6 & 7 & 18 & 6 & 2 & 2 \\
\hline Antechinus sp. cf. A. flavipes & 2 & 1 & 2 & & & \\
\hline Indet. small dasyurid & 8 & 7 & 2 & & & \\
\hline Phascogale tapoatafa & 2 & 1 & & & & \\
\hline Total small dasyurids & 100 & 80 & 124 & 26 & 44 & 13 \\
\hline Dasyurus viverrinus & 3 & 1 & 1 & & & \\
\hline Dasyurus maculates & 2 & & & & & \\
\hline Nyctophilus geoffroyi & 1 & 1 & 1 & & & \\
\hline Nyctophilus gouldii & 1 & 1 & 1 & & & \\
\hline Falsistrellus tasmaniensis & 1 & & & & & \\
\hline Scotorepens sp. & 1 & & & & & \\
\hline Total microchiropterans & 1 & 2 & 2 & 2 & 1 & \\
\hline Oryctolagus cuniculus & 1 & & & & & \\
\hline Total mammals & 1132 & 884 & 745 & 215 & 329 & 83 \\
\hline Scincidae & 8 & 20 & 11 & 2 & & \\
\hline Elapidae & 1 & & & & & \\
\hline Birds & 1 & 2 & 4 & 4 & 1 & \\
\hline Total all vertebrates & 1141 & 906 & 760 & 215 & 336 & 84 \\
\hline
\end{tabular}




\section{Stratigraphy and dating}

The surface sediments (Unit I) of the excavation are unconsolidated, organic, rich, brown, loamy sediment with a small quantity of limestone rubble and organic litter, including visible wood-charcoal fragments. The density of bone and charcoal was noted to increase between Spit $S$ and Spit 1. Spit 2 maintained the high density of bone and charcoal; it was removed to expose a distinctly greyer unit across the entire square. Spits 3 and 4 removed this sub-unit, which was also found to contain abundant bone and charcoal. An undulating flowstone horizon was exposed locally in Spit 3 and across the entire square on completion of Spit 4, with a vertical fall of 3-4 cm from north to south. The flowstone consists of a 1-2 mm thick layer of relatively clean calcite, sealing partially brecciated sediments; it was broken through and the underlying bone and charcoal-rich unit removed in two spits (5 and 6). The flowstone and Spits 5-6 are grouped as Unit II. Spit 6 exposed a second and more substantial flowstone across the entirety of the square, this time showing a vertical fall of $5 \mathrm{~cm}$ from north to south. This lower flowstone was also broken through but only over the northern half of the square. Excavation proceeded in this reduced area for three spits, by breaking up the brecciated sediments with a small crowbar. The sediment contained a much larger quantity of limestone rubble than the upper units, as well as rounded fragments of a hard, red claystone of uncertain origin. While this superficially resembles burnt sediments from hearths, final identification is reserved pending microscopic examination. The lower flowstone and underlying sediments are designated as Unit III. Section drawings illustrate the relative thickness of the recognised stratigraphic units (Figure 3).

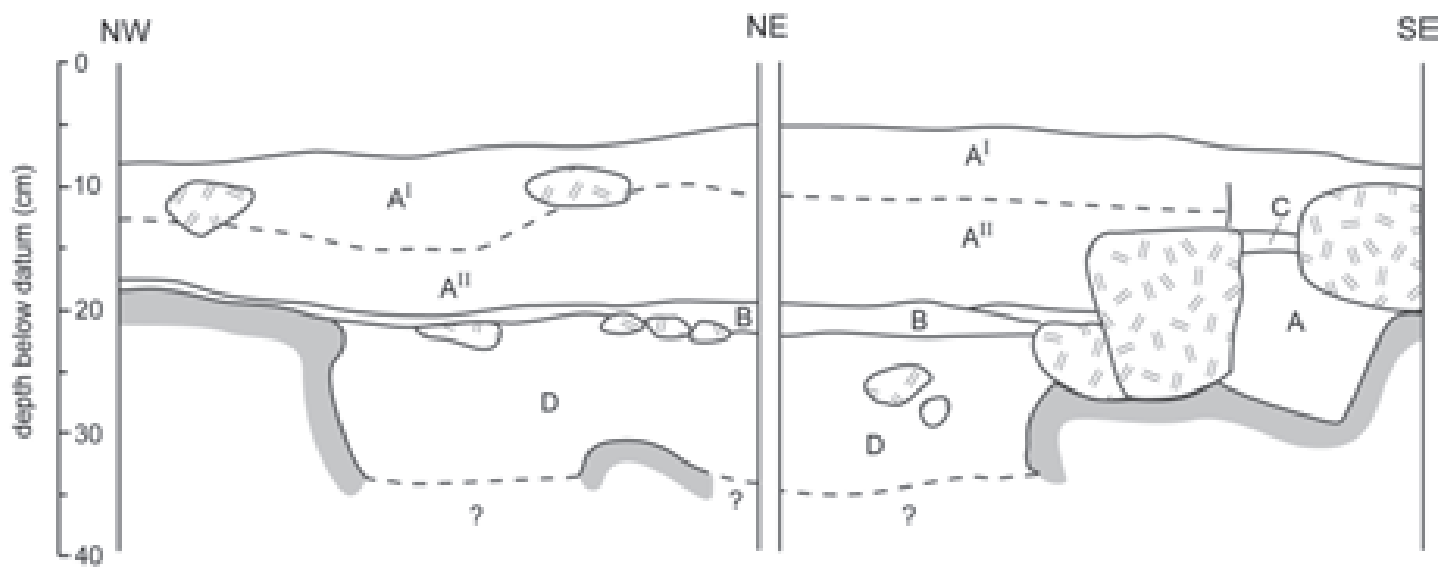

Figure 3. Section drawings for the NE and NW walls of the excavation in Y259. Unexcavated deposit of unknown depth is indicated at the bottom of each section. Limestone blocks are shown with crosshatch. The fine layer of flowstone that separates Units I and II was not obvious in the section; its approximate position, based on depth measurements at the time of excavation, is indicated by the dashed line

The presence of the two unbroken flowstone units gives us great confidence that our excavation was placed away from any disturbance caused by Drummond (1963). Furthermore, the sharp nature of the upper surface of both flowstones, compared with their more diffuse lower boundaries, together with the north-to-south dip on both surfaces, suggests to us that each flowstone was deposited during a brief hiatus in sedimentation, and that they represent primary features in the stratigraphy. The point is of interest in so far as it impacts on our perception of the level of stratigraphic integrity of the deposit and contained faunal and cultural sequence, which would clearly be poorer if formation of the flowstones substantially postdated the main period of accumulation (and potential disturbance) of the deposit. Moreover, if the features are primary, then the consistent dip on both flowstone-sealed surfaces indicates that the bulk of the sediments entered the deposit from the northern side, i.e. the main doline, rather than through the more elevated southern entrance. The origin of the flowstones might 
be tested by direct dating of the calcites relative to charcoal in the underlying and overlying sedimentary units.

Two AMS dates were obtained on discrete chunks of wood charcoal removed from weakly brecciated sediments of Spits 7 and 9, respectively (Table 2). The results indicate a relatively rapid accumulation of Unit III during the early Holocene, in the interval between 9700 and 9120 cal. yr BP.

Table 2. Radiocarbon dates from Y259. Dates were produced by the University of Waikato Radiocarbon Dating Laboratory using Accelerator Mass Spectrometry. Calibrated ages are based on 0xCal v3.10 (Bronk Ramsey 2001)

\begin{tabular}{|l|l|l|l|l|l|}
\hline Spit & Lab code & Material & $\mathrm{d} 13 \mathrm{C}(\%)$ & Radiocarbon age & $\begin{array}{l}\text { Southern Hemisphere Calibration 2 } \\
\text { sigma interval }\end{array}$ \\
\hline 7 & Wk-18838 (AMS) & Charcoal & $-25.6 \pm 0.2$ & $8343 \pm 43 \mathrm{BP}$ & $9440-9120 \mathrm{cal} \mathrm{yr} \mathrm{BP}$ \\
\hline 9 & Wk-18839 (AMS) & Charcoal & $-25.3 \pm 0.2$ & $8668 \pm 43 \mathrm{BP}$ & $9700-9500 \mathrm{cal} \mathrm{yr} \mathrm{BP}$ \\
\hline
\end{tabular}

\section{The faunal assemblage}

Substantial quantities of bone were recovered from all excavated levels. The assemblages from Spits $S$ and 1 are comprised entirely of large quantities of unburnt and mostly unbroken bones derived from small to medium-sized mammals, with occasional remains of birds and reptiles (Table 1 and Figure 4). The samples from Spits 5 (Unit II) and Spits 7-9 (Unit III) are similar except that the assemblages also contain small numbers of mostly fragmented bones derived from larger-bodied mammals. In Unit III, a significant proportion of these larger bone fragments is also burnt to varying degrees.

\section{Taphonomy}

We interpret the Y259 assemblage as a composite of two faunal components with distinct origins. The first component, comprising the bulk of the remains from each level, is interpreted as the dissociated remains of regurgitated pellets or 'casts' deposited by owls on to the cave floor from their daytime roosts. Signature characteristics of a bone deposit accumulated by owls include a preponderance of nocturnally active small mammals over larger-bodied mammals and diurnally active vertebrates (e.g. birds or reptiles), a large proportion of intact skeletal elements, and an absence or low incidence of burning (Wakefield 1972b; Kusmer 1990). The largest mammals in Spits $S$ and 1 are possums, rat kangaroos and bandicoots, but these are represented primarily by juveniles.

Three species of owls found in southeastern Australia are known to roost in caves and to accumulate large quantities of prey remains - sooty owl (Tyto tenebricosa), masked owl (Tyto novaehollandiae) and barn owl (Tyto alba). All have been recorded in the region of the deposit (Table 3), although sooty and masked owls are currently rare or vagrant. Clear criteria for distinguishing the prey accumulations of each species have not been established. However, the larger-bodied sooty and masked owls are understood to be capable of taking a wider size range of prey than the smaller-bodied barn owl, while sooty owls are thought to forage more often in wetter forests than masked owls, and to make greater use of arboreal mammals (Morton et al. 1977; Lundie-Jenkins 1993; Kavanagh and Murray 1996; Bilney et al. 2006). The relatively poor representation of arboreal mammals in the Y259 assemblage suggests that masked owls and/or barn owls may have been responsible for the bulk of the bone accumulation.

The second component of the assemblage, confined to Units II and III, is interpreted as prey remains deposited by occasional human visitors to the site. This component is most clearly indicated by the representation of larger mammals, such as several species of wallabies, that are considerably beyond the predatory capacity of owls, and by the physical condition of 
the remains of these larger animals, which are typically fragmented and, at least in Unit III, often show signs of heat modification, whether from cooking or post-discard burning. Careful examination of the samples of burnt bone from each of Spits 7 to 9 shows they are primarily derived from medium-sized to large mammals, and only rarely from small mammals.

Some caution must be exercised in interpreting burnt bone as an indicator of human predation or activity (Nicholson 1993; Asmussen 2009). Bone can burn in natural bushfires and it might conceivably have washed into the cave from outside. In the present case, we regard this as unlikely, for two reasons. Firstly, none of the larger mammal bones, including the various burnt specimens, show any rounding of fracture edges of the kind that typifies bone subject to overland transport. And secondly, many of the burnt bones show extreme charring and even calcination, due to heating to temperatures well above those usually attained under a natural fire (Nicholson 1993; Stiner et al. 1995). We conclude that the bones were burnt in or below hearths, probably situated within the cave itself. But does this imply human predation? Again, not necessarily so, as construction of a hearth on a cave deposit rich in non-cultural bone presumably can result in intense burning of buried bones. While this might explain some of the burnt bone in Y259, we believe that most of the burnt bones are the remains of animals that were either hunted or scavenged by people, and then cooked, eaten and their

Table 3. Faunal comparison of Y259 to surrounding faunal records based on records within the New South Wales Wildlife Atlas (Table 3 continues on page 198)

\begin{tabular}{|c|c|c|c|}
\hline Taxa recorded in Y259 & $10 \mathrm{~km}$ & Alps & Bago \\
\hline \multicolumn{4}{|l|}{ Marsupials } \\
\hline \multicolumn{4}{|l|}{ Dasyurids } \\
\hline Antechinus sp. cf. A. flavipes & & & + \\
\hline Antechinus agilis & + & + & + \\
\hline Antechinus swainsonii & & + & + \\
\hline Dasyurus maculates & + & + & + \\
\hline Dasyurus viverrinus & & + & \\
\hline Phascogale tapoatafa & & + & + \\
\hline \multicolumn{4}{|l|}{ Sminthopsis leucopus } \\
\hline \multicolumn{4}{|l|}{ Sminthopsis murina } \\
\hline \multicolumn{4}{|l|}{ Bandicoots } \\
\hline Perameles nasuta & & + & + \\
\hline Isoodon obesulus & & & + \\
\hline \multicolumn{4}{|l|}{ Macropodoids } \\
\hline \multicolumn{4}{|l|}{ Bettongia sp. } \\
\hline Potorous sp. & & & + \\
\hline Macropus rufogriseus & + & + & + \\
\hline Petrogale penicillata & & + & \\
\hline \multicolumn{4}{|l|}{ Possums and gliders } \\
\hline Acrobates pygmaeus & & + & + \\
\hline Cercartetus nanus & + & + & + \\
\hline \multicolumn{4}{|l|}{ Gymnobelideus leadbeateri } \\
\hline Petaurus australis & & + & + \\
\hline Petaurus breviceps & + & + & + \\
\hline Pseudocheirus peregrinus & + & + & + \\
\hline Trichosurus sp. & + & + & + \\
\hline \multicolumn{4}{|l|}{ Murid rodents } \\
\hline Mastacomys fuscus & + & + & + \\
\hline
\end{tabular}




\begin{tabular}{|c|c|c|c|}
\hline Taxa recorded in Y259 & $10 \mathrm{~km}$ & Alps & Bago \\
\hline Pseudomys fumeus & + & + & + \\
\hline \multicolumn{4}{|l|}{ Pseudomys higginsi } \\
\hline \multicolumn{4}{|l|}{ Pseudomys novaehollandiae } \\
\hline \multicolumn{4}{|l|}{ Pseudomys oralis $A$} \\
\hline \multicolumn{4}{|l|}{ Pseudomys oralis B } \\
\hline Rattus fuscipes & + & + & + \\
\hline \multicolumn{4}{|l|}{ Rattus lutreolus } \\
\hline \multicolumn{4}{|l|}{ Introduced mammals } \\
\hline Oryctolagus cuniculus & + & + & + \\
\hline \multicolumn{4}{|c|}{ Potential owl species contributing to deposit } \\
\hline Tyto alba & + & + & + \\
\hline Tyto novaehollandiae & & + & \\
\hline Tyto tenebricosa & & + & \\
\hline \multicolumn{4}{|c|}{ Potential owl prey not recorded in Y259 } \\
\hline Burramys parvus & & + & \\
\hline Hydromys chrysogaster & & + & + \\
\hline Petauroides volans & & + & + \\
\hline Petaurus norfolcensis & & + & + \\
\hline \multicolumn{4}{|l|}{ Introduced mammals } \\
\hline Mus musculus & + & + & + \\
\hline Rattus rattus & + & + & + \\
\hline \multicolumn{4}{|c|}{ Potential human prey not definitively recorded in Y259 } \\
\hline Macropus giganteus & + & + & + \\
\hline Macropus robustus & & + & + \\
\hline Phascolarctos cinereus & & + & + \\
\hline Pteropus scapulatus & & & + \\
\hline Tachyglossus aculeatus & + & + & + \\
\hline Vombatus ursinus & + & + & + \\
\hline Wallabia bicolour & + & + & + \\
\hline
\end{tabular}

remains discarded into hearths. To argue that the larger mammal bones might have entered the site naturally and been burnt coincidently beneath a hearth, it would be necessary to explain the absence of burning of more than just a few of the very large number of associated small mammal bones that littered the cave floor during accumulation of Unit III.

\section{Taxonomic composition}

The faunal assemblages from each of the analysed samples are summarised in Table 1 and Figure 4. A minimum of 33 species of mammals is represented, along with at least one species of skink and several different but currently undetermined bird species.

The various samples differ in both gross composition and detailed taxonomic representation. Looking first at gross composition (Figure 4a), a clear difference is seen between Unit III, where wallabies make up from $20 \%$ to $40 \%$ of total NISP, and Unit I, where these taxa are not represented at all. As argued above, the wallaby remains almost certainly represent a distinct archaeological (i.e. human-derived) component, present within the assemblage from Unit III, but absent from the two uppermost samples. The sample from Unit II, in which wallabies make up $4 \%$ of total NISP, is intermediate in this regard and may include a small archaeological (i.e. human-derived) component. 


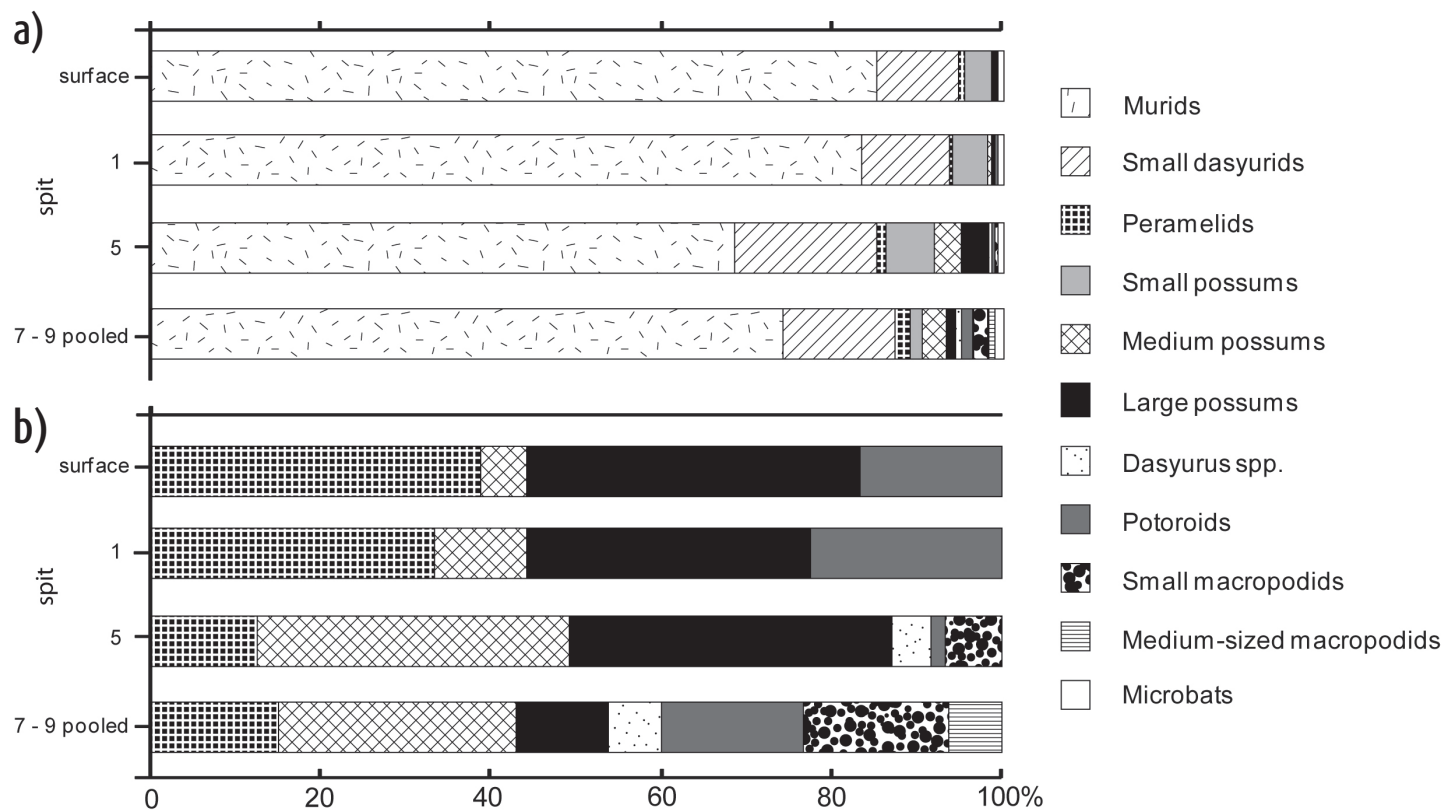

Figure 4. Summary taxonomic composition of the Y259 vertebrate fauna recovered from each of Spits $S$ and Spit 1 (Unit I), Spit 5 (Unit II), and combined Spits 7-9 (Unit III). Plotted values are based on NISP. Figure 4a includes all taxa; 4b excludes the smallest mammals

If wallabies are excluded from these calculations, the samples from Units II and III are still distinguished in having a higher proportion of medium-sized mammals, especially possums, a slightly higher proportion of small dasyurids, and correspondingly fewer murids (Figure $4 \mathrm{~b})$. The presence of possum-sized bones among the fragmented and burnt component of the Unit III samples suggests that some of the medium-sized mammals are a product of human predation. However, it is also possible that the change reflects a decreased emphasis on medium-sized mammals by the avian predators, perhaps due to a greater contribution by barn owls during more recent times. Both factors may be partly responsible for the observed changes.

A notable feature of the finer-scale taxonomic composition is the dominance throughout of three murids, Rattus fuscipes, Mastacomys fuscus and Pseudomys fumeus, which together contribute 53\% (Spit 9) and 78\% (Spit S) of the total NISP for mammals. The following temporal changes are apparent among the numerous sub-dominant taxa:

1. Recent loss of Sminthopsis leucopus (present in Spit 1 and below but absent in the large sample from Spit $S$ );

2. Earlier loss of Gymnobelideus leadbeateri (present in Spit 5 and below; absent in Spits 1 and S) and coincident reduction in each of Pseudomys novaehollandiae, Antechinus swainsonii (both still present in Spits 1 and S but more abundant in Spit 5 and below) and Sminthopsis spp. overall;

3. Apparent absence of Perameles nasuta above Spit 5 and coincident appearance of Isoodon obesulus; and

4. Considerable increase in abundance in Spit 5 and above of Cercartetus nanus.

Notable absences from all samples are the greater glider (Petauroides volans), squirrel glider (Petaurus norfolcensis), mountain pygmy possum (Burramys parvus), and rabbit rat (Conilurus albipes). The mountain pygmy possum and rabbit rat are likely to be precluded due to habitat preferences (see Discussion). However, the absence of the larger gliders from deposits is enigmatic, particularly given the abundance of $P$. volans in nearby forests today. 
The introduced rabbit (Oryctolagus cuniculus) is represented only in Spit S. Several rabbit skeletons were found in the nearby entrance of Y50, and it seems likely that rabbit material may not be derived from avian predators, but from incidental deaths in the cave, or from dog or fox activity. This interpretation is supported by the absence of Mus musculus and Rattus rattus. Drummond (1963) was not confident in stating that non-native species were absent from the cave deposit because he was unable to differentiate Rattus species; however, it seems that all species in the owl-derived fauna are native, and the deposition of such material appears to have ceased in Y259 before the local arrival of introduced murids.

\section{Stone artefacts}

Artefacts were recovered only from Spits 7, 8 and 9 (Table 4). A total of 16 specimens display unambiguous signatures of human manufacture, such as positive hertzian fractures, with clear platforms and, in most cases, negative dorsal scars from the same platform, indicating that they were struck from uni-platform cores. The clustering of artefacts in Spits 7-9 may indicate one relatively intensive phase of human use of the site. However, multiple visits to the site are indicated by the different raw materials in each of the spits: all artefacts in Spit 9 are volcanic, whereas all artefacts in Spit 7 are quartz, while chert is present only in Spit 8 (Table 4). These patterns are unlikely to result from taphonomic processes and are best seen as the product of multiple, discrete periods of human visitation.

Table 4. Description of the stone artefacts from Y259

\begin{tabular}{|c|c|c|c|c|c|}
\hline \multirow[t]{2}{*}{ Spit } & \multirow[t]{2}{*}{ Raw material } & \multicolumn{3}{|c|}{ Flake dimensions in $\mathrm{mm}$} & \multirow[t]{2}{*}{ Description } \\
\hline & & Length & Width & Thickness & \\
\hline 7 & Quartz & 11.4 & 5.6 & 1.8 & Complete tertiary flake with feather termination \\
\hline 7 & Quartz & 3.1 & 4.7 & 2.4 & Medial flake fragment \\
\hline 7 & Quartz & 4.2 & 5.5 & 2.5 & Proximal fragment of tertiary flake \\
\hline 8 & $\begin{array}{l}\text { Sedimentary } \\
\text { (chert) }\end{array}$ & 7.0 & 4.0 & 1.1 & Proximal fragment of tertiary flake \\
\hline 8 & Quartz & 5.9 & 8.4 & 2.5 & Medial flake fragment \\
\hline 8 & Quartz & 7.7 & 6.6 & 1.8 & Complete tertiary flake \\
\hline 8 & Volcanic (tuff) & 7.0 & 6.0 & 2.8 & Distal fragment with feather termination \\
\hline 8 & Volcanic (tuff) & 10.9 & 6.3 & 2.1 & Flake fragment \\
\hline 8 & Quartz & 10.9 & 10.0 & 3.1 & Longitudinally split flake with feather termination \\
\hline 8 & $\begin{array}{l}\text { Sedimentary } \\
\text { (chert?) }\end{array}$ & 8.8 & 10.6 & 1.6 & Complete tertiary flake with feather termination \\
\hline 8 & Volcanic (tuff) & 13.3 & 15.6 & 2.6 & Distal fragment with step termination \\
\hline 8 & Volcanic (tuff) & 13.2 & 20.9 & 2.6 & Complete flake with cortex on dorsal face \\
\hline 8 & Volcanic & 30.8 & 17.5 & 4.8 & Complete tertiary flake with shattered platform \\
\hline 9 & Volcanic & 10.4 & 9.1 & 1.5 & Complete tertiary flake with step termination \\
\hline 9 & Volcanic & 8.3 & 4.2 & 1.6 & Flake fragment \\
\hline 9 & Volcanic & 7.7 & 20.1 & 6.2 & Complete tertiary flake with feather termination \\
\hline
\end{tabular}

The stone artefacts are all unretouched flakes, hence are not diagnostic of particular functions or activities. As shown in Figure 5, none are fewer than $3 \mathrm{~mm}$ in length or $4 \mathrm{~mm}$ in width. Since the sieve size used in excavation was smaller than this and the samples were carefully sorted, the lack of small artefacts between $1 \mathrm{~mm}$ and $3 \mathrm{~mm}$ is significant. Knapping of stone artefacts typically produces large quantities of small fragments in the 1-3 mm range 
and these are a reliable indicator of artefact manufacture in a site. In the case of Y259, the absence of artefacts of that size class reveals that artefacts were typically made elsewhere, either in a different site or a different part of this site, and that limited artefact reduction occurred here. This pattern is consistent with short-term visits to the cave by mobile groups which were transporting retouched flakes or cores made elsewhere and which undertook only very limited amounts of stone working when occupying Y259.

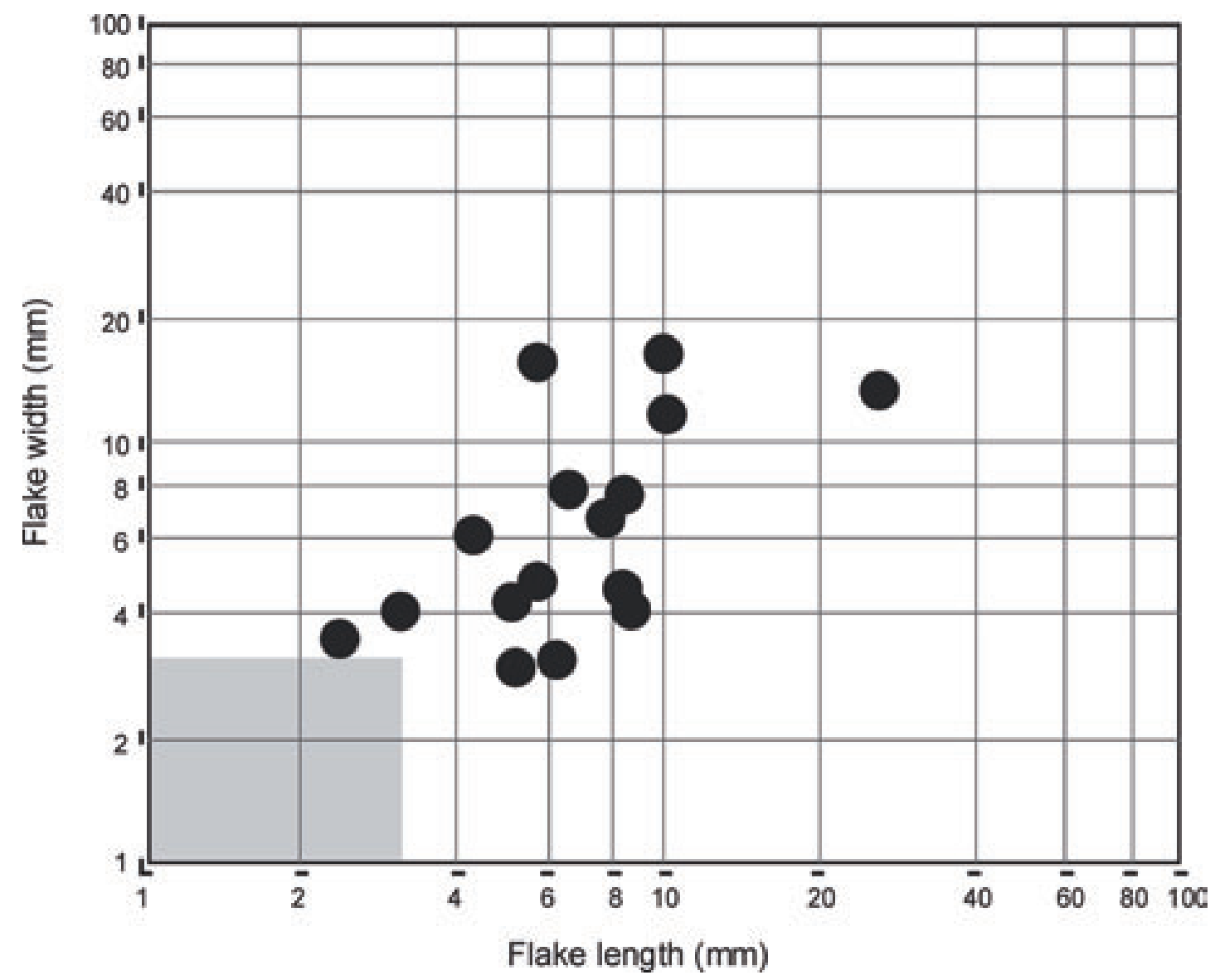

Figure 5. Scatterplot of the dimensions of stone artefacts in Y259. Grey area shows dimensions between $1 \mathrm{~mm}$ and $3 \mathrm{~mm}$ where on-site stone working debris is expected to fall

\section{Discussion}

The cave-floor deposit in Y259 provides important new information on three separate topics of interest for the natural and human history of the Southeastern Highlands. These are: (1) The nature of the 'original', pre-European mammal fauna; (2) Environmental conditions during the early Holocene; and (3) The history of aboriginal occupation.

\section{The 'original' pre-European mammal fauna}

This topic is the subject of a wider investigation involving many more sites and will be treated in full elsewhere. However, a number of important observations warrant mention in this context. As contended by Drummond (1963), the 'original' fauna (i.e. very late prehistoric into early historical times) of the Yarrangobilly Plateau recorded in Y259 was substantially more diverse than the fauna recorded by modern records from the surrounding bioregions (Table 3). Drummond's (1963) list of 14 mammal species from Y259 is a subset of those reported herein, with the exception of Pseudomys australis (see taxonomic comments above). 
Hope (1976) listed 18 terrestrial mammals and three bats from five caves at Yarrangobilly, based on surface collections made by M. and J. Mendrum and R. Curtis in 1970-72. This also represents a subset of the more extensive list obtained from Y259, but with the addition of two larger marsupials (Phascolarctos cinereus and Vombatus ursinus) and one bat (Chalinolobus morio). Seebeck and Johnson (1980) noted a partial subfossil skull of Potorous longipes from a nearby cave at Yarrangobilly, and we have also collected remains of this species (as well as $P$. tridactylus) from other nearby sites. Taxa recorded from the surface of Y259 and other sites at Yarrangobilly but never recorded as living animals in the surrounding region include: Sminthopsis murina, Isoodon obesulus, Dasyurus viverrinus, Rattus lutreolus, Pseudomys higginsi, Pseudomys oralis, Pseudomys novaehollandiae, Potorous tridactylus, Potorous longipes and Bettongia gaimardi. Several of these taxa (D. viverrinus, B. gaimardi) are presumed extinct on the Australian mainland, while others (I. obesulus, Potorous tridactylus, Pseudomys oralis, $R$. lutreolus) persist only on the eastern slopes of the Great Divide and along the coast. Sminthopsis leucopus is found in Spit 1 of Y259 and near-surface or surficial contexts in nearby caves.

Sminthopsis murina is broadly distributed across southeastern Australia but is most commonly found in open forest, woodland and heathland. The species has been recorded above $1200 \mathrm{~m}$ asl in the Blue Mountains region, but is unknown from the Australian Alps, although it occurs in adjacent lowland habitats near Canberra. In near-coastal habitats, $S$. murina attains its highest population densities at mid-successional stages after fire (Fox 2008). Sminthopsis leucopus is similar in its general ecology to S. murina (Wakefield 1972b; Lunney et al. 1989), and replaces that species in near-coastal habitats along the southern New South Wales and Victorian coasts and in Tasmania. It occurs at up to $900 \mathrm{~m}$ asl on the coastal scarp west of Bega.

Of the two bandicoots, Perameles nasuta is still regionally present in montane forests, although it is not recorded in Spit S. Although P. nasuta occupies a wide range of habitats, foraging activity tends to focus on open, grassy patches. Dickman and Stoddart (2008:189) state that it is 'most abundant at elevations of less than $1000 \mathrm{~m}$ that receive an annual rainfall of more than $750 \mathrm{~mm}$ '. In contrast, the regionally extinct Isoodon obesulus prefers to forage in dense understorey and avoids more open habitat (Claridge 1988). Surviving populations in eastern Australia tend to be associated with sandy substrate and heaths in near-coastal contexts.

The lack of contemporary regional records of Dasyurus viverrinus, Bettongia gaimardi and the two Potorous species is unsurprising given the scant representation of these taxa in historic collections and their widespread recent declines. Where taxa occur so infrequently in the cave deposits, direct dating of bones may be necessary to accurately document their history of decline.

The area around Y259 once possessed a rich rodent community that included Pseudomys fumeus, P. higginsi, P. novaehollandiae, P. oralis (A and B) and Mastacomys fuscus. In common with most of southeastern Australia, historical rodent records from the region are almost exclusively of Rattus fuscipes, which is also by far the most abundant taxon in the surficial unit of Y259 and also in all deeper levels. Happold (1989) recorded it from all elevations up to $2200+\mathrm{m}$ and in all habitats including forests, heathlands and boulder fields, although a general preference for wetter gullies and denser understorey typifies its preferred habitats (Bennett 1993). At Happold's main study site at c. 1600 m, near Smiggins Hole, R. fuscipes was captured in approximately equal numbers to $A$. swainsonii and $M$. fuscus. The extreme dominance of $R$. fuscipes in Y259 is difficult to explain purely in terms of habitat characteristics. This percentage dominance may be a result of the lack or very low abundance of other rodents such as Pseudomys oralis and $P$. novaehollandiae, rather than unusually high local abundance of $R$. fuscipes. The former species are much more abundant at lower-altitude sites in the region, contributing up to $46 \%$ of rodents at nearby sites (Ford et al. In prep). 
Pseudomys fumeus is a very rare component of the modern Yarrangobilly fauna. It has never been captured live despite targeted surveys, and only three recently dead animals found in 1998 prove its continued existence (Ford 1998). Throughout the past 10,000 years, it was probably the second most abundant member of the forest rodent fauna, until it succumbed to the impacts of European colonisation. This species seems to prefer habitats with prominent heath and legume species, and thus tends to favour locally drier sites within the forest matrix; however, it has been recorded occupying wetter gullies (Ford et al. 2003).

Pseudomys novaehollandiae is found across a wide latitudinal range (Tasmania to south Queensland) and in a broad range of habitats from coastal heaths to moist open eucalypt forest (Lock and Wilson 1999). Most extant populations have a preference for sandy substrates which tend to develop a heath ground cover, and populations appear to peak six months to several years after fire (Fox and Fox 1978; Haering and Fox 1997). The species is only locally abundant in a few locations in northeastern NSW and coastal populations south of Sydney are small, isolated and extinction prone. The only known surviving inland population occurs in dry heaths of the Hervey Range, east of Parkes.

Pseudomys oralis has not been captured within $500 \mathrm{~km}$ of Yarrangobilly. It has been recorded as a subfossil from sites as far south as Buchan Caves (Wakefield 1972b), but living animals are known only from the Barrington Tops area northwards to the Lamington Plateau (Jerry et al. 1998). It seems to favour generally wetter forest mosaics, but will frequent open drier habitat components (Read and Tweedie 1996; Smith and Quin 1996). The specific ecological attributes of the two tentative taxa identified from Y259 are not known.

Mastacomys fuscus still occurs in the Yarrangobilly region, but is only patchily present, and seemingly rare compared with abundances in the Y259 deposit. It has disappeared from loweraltitude sites throughout the Southern Tablelands in the past 200 years (Ford et al. In prep), only persisting in the higher altitudes of Kosciuszko National Park and nearby state forests, usually inhabiting boulderfields, heaths and grasslands (Green and Osborne 2003). It still occurs at lower altitudes and in a broader range of habitats in Victoria (Wallis 1992).

Pseudomys higginsi was first identified on mainland Australia by Wakefield (1972a). Subsequent work by Wakefield (1972b) and Hope (1976) recorded the species in various deposits of confirmed or inferred late-Pleistocene age, usually found in association with Burramys parvus. Flood (1980) dated the apparent disappearance of P. higginsi from the Buchan area to the interval 14,000-17,000 BP, coincident with the last phase of continental deglaciation (Barrows et al. 2001; Turney et al. 2006), and noted its apparent replacement at that time by the similar-sized $P$. oralis. The present record of $P$. higginsi from a surface context in Y259 suggests that this species persisted in the Southeastern Highlands until quite recent times. This has been confirmed by direct dating by AMS of bones of this taxon to less than 500 years old from other sites in the Yarrangobilly region (Breed and Ford 2007; Ford et al. In prep).

Tasmanian populations of $P$. higginsi occupy a wide range of habitats, including rainforests, wet sclerophyll forest, open sclerophyll forests and boulder-strewn habitats (Stoddart and Challis 1991). The habitat preferences of mainland populations of P. higginsi are unknown. However, given its history of post-glacial reduction in range and apparent retreat to higherelevation regions, it is reasonable to infer a preference for relatively cooler habitats. Direct dating of numerous referred bones is needed to establish the precise timing of distributional changes and the mainland disappearance of this species, however it almost certainly persisted at higher altitudes into historical times.

\section{Early Holocene climate and environment}

The last deglaciation of the Australian Alps was complete by 16,000 years ago (Barrows et al. 2001; Turney et al. 2006). Despite a return to cooler conditions during the Younger Dryas 
(c. 13,000-11,500 years ago; Peteet 1995; Alley and Clark 1999; Andres et al. 2003), trees are registered locally at upland sites during this period, and by 10,000 years ago the tree line had attained its current position across the region (Kershaw and Strickland 1989; Martin 1999). Peat was forming in moist sites at $1000 \mathrm{~m}$ asl before the Younger Dryas, and in higherelevation mires during the earliest Holocene (Kershaw and Strickland 1989; Hope 2003), suggesting widespread, early stabilisation of slope habitats.

In most parts of the world, climate proxies show a prolonged period of warm conditions during the early Holocene, beginning around 10,000 years ago and continuing for at least 4000 years (Grootes et al. 1993; Stager et al. 1997; Wang et al. 2001; Zhou et al. 2004). Mean annual temperatures probably peaked at c. 9500 years ago, with values $3^{\circ} \mathrm{C}$ above modern values at mid-latitudes in the northern hemisphere (Foley et al. 1994; Morgan et al. 2002). The 'Holocene Optimum' is registered in many Australian climate proxy records. In the southeast Australian Alps, regional palynological records show an increase in wet sclerophyll forest elements, most notably the understorey shrub Pomaderris (the 'Pomaderris Interval'), commencing c. 9700 years ago and probably continuing until c. 4500 years ago (Kershaw and Strickland 1989; Martin 1999; Hope et al. 2004; Kershaw et al. 2007). Rapid growth of mires in the region is observed through the same time interval (Hope 2003). Lakes in southeastern Australia register their highest levels for the Holocene slightly later, between 7600 and 5500 years ago (Bowler 1981; D'Costa et al. 1989; Chivas et al. 1993). This is coincident with evidence for reduced regional aeolian activity (Stanley and De Deckker 2002).

The ${ }^{14} \mathrm{C}$ determinations for Unit III of Y259 correspond with the peak of the 'Holocene Optimum', and with the time of establishment of wetter forest communities throughout the surrounding region. The faunal assemblage from this period has several noteworthy characteristics, including the presence of Gymnobelideus leadbeateri and Perameles nasuta, the relatively high abundance of small dasyurids, especially Antechinus swainsonii and S. leucopus, and the relative scarcity of two species, Pseudomys higginsi and Cercartetus nanus. A crude method was used to aid interpretation of the potential climatic implications of the observed faunal changes. We compared climate attributes produced by BIOCLIM for the Y259 site (Table 5) with climate profiles for six mammal species and for the sooty owl, based on known living populations (Bennet et al. 1991). The current climate of Y259 falls within the climatic range currently occupied by five of the six mammal species and the sooty owl, despite the fact that two of the mammals, Isoodon obesulus and Pseudomys novaehollandiae, have suffered widespread local extinctions over the past 150 years and their modelled climatic preferences probably are not representative of their full natural range. In contrast, the mountain pigmy possum (Burramys parvus), a species today found only above $1300 \mathrm{~m}$ asl in the Australian Alps bioregion, has a climatic profile that is significantly wetter and colder than the Y259 locality. This species occurs regionally in deposits of late-Pleistocene age down to much lower elevations (Wakefield 1972b; Ride et al. 1989), and its absence from Y259 is consistent with the notion that the earliest part of the excavated sequence samples the wetter, warmer conditions of the early Holocene, rather than the preceding colder conditions of the Last Glacial Maximum.

Gymnobelideus leadbeateri is recorded as a living animal only in eastern Victoria. Previously published records of $G$. leadbeateri outside its current range include the Broom Breccia at Wombeyan, and Pyramids Cave, Buchan (primarily in the older 'Reddish Fraction'; minor representation in the younger 'Whitish Fraction') (Wakefield 1972b). In both of these assemblages, G. leadbeateri occurs with Burramys parvus in deposits that are presumed to be of late-Pleistocene antiquity. One other occurrence is from Marble Arch, near Braidwood (Hall 1975), where it occurs in association with an entirely modern fauna, though from an undated sub-surface context. The immediate local environment around Marble Arch is wet sclerophyll forest. Although the occurrence of $G$. leadbeateri in the Broom Breccia and Pyramids 'Reddish Fraction' faunas seems somewhat anomalous, the bulk of the evidence for this species suggests an association with wetter forest communities and warmer (lower-elevation) sites. The presence 
Table 5. Comparison of the contemporary climate of Y259, representing the Yarrangobilly Plateau, with the current climatic profiles of six mammal species and one owl species

\begin{tabular}{|c|c|c|c|c|c|c|c|c|}
\hline Climate variable & Y259 & I. $o b^{1}$ & $G . l e^{2}$ & B. $p a^{3}$ & M. $f u^{4}$ & P. $n o^{1}$ & P. $f u^{4}$ & T. $t e^{5}$ \\
\hline \multicolumn{9}{|l|}{ Temperature $(\underline{0} \underline{\mathrm{C}})$} \\
\hline Annual mean & 9.4 & +4.5 & +.01 & -4.2 & Same & +4.6 & +0.3 & +1 \\
\hline Min of coldest period & -1.6 & +5.7 & +2 & -2.7 & Same & +5.4 & +2 & +2.9 \\
\hline Max of warmest period & 24.1 & +0.5 & Same & $\underline{-6.5}$ & Same & +0.7 & Same & Same \\
\hline \multicolumn{9}{|l|}{ Precipitation $(\mathrm{mm})$} \\
\hline Annual & 1212 & -260 & +281 & +325 & +82 & -71 & Same & Same \\
\hline Wettest quarter & 390 & -79 & +64 & +74 & Same & -15 & Same & Same \\
\hline Driest quarter & 213 & -43 & +29 & +74 & +12 & -2 & Same & Same \\
\hline Coldest quarter & 387 & -88 & +40 & +48 & Same & $\underline{-108}$ & Same & Same \\
\hline Warmest quarter & 215 & -41 & +40 & +84 & +24 & Same & Same & -3 \\
\hline
\end{tabular}

Y259 values are based on BIOCLIM modelling performed according to the protocols of Bennett et al. (1991) from which species climate profiles were taken. 'Same' indicates that the Y259 value falls between the 25 th and 75 th percentiles of a species' climate profile. Numbers indicate the difference between a species' relevant percentile and the site value (e.g. +4.5 indicates that the $25 \%$ percentile (cooler end of the range) of annual temperature for Isoodon obesulus sites is $4.5^{\circ} \mathrm{C}$ higher than the site value for Y259, while the 75th percentile (warmer end of range) for Burramys parvus sites is $4.2^{\circ} \mathrm{C}$ lower than Y259). Values which fall outside the recorded range for all sites for a species are underlined. Note that profiles for recently extinct species are skewed by incomplete sampling of potential climatic range. I. ob = Isoodon obesulus; G. le = Gymnobelideus leadbeateri; B. pa = Burramys parvus; $\mathrm{M} . \mathrm{fu}=$ Mastacomys fuscus; P. no $=$ Pseudomys novaehollandiae; $\mathrm{P}$. fu = Pseudomys fumeus; $\mathrm{T}$. te = Tyto tenebriosca.

${ }^{1}$ Recent (post-European) local extinction. ${ }^{2}$ Natural local extinction during mid? Holocene. ${ }^{3}$ Not yet recorded in Y259. ${ }^{4}$ Still locally present around Y259. ${ }^{5}$ Some evidence of occasional local occurrence

of G. leadbeateri in Unit II demonstrates that it survived on the Yarrangobilly Plateau until sometime after 9000 years ago.

The peak abundance of small dasyurids during the early Holocene might reflect regionally higher productivity of forest communities, possibly associated with warmer and longer growing seasons. All members of this group are strictly animalivorous and feed primarily on terrestrial and arboreal invertebrates, variably supplemented by worms. Two species in particular are considerably more abundant in Unit III than in Unit I. Antechinus swainsonii has a broad altitudinal and latitudinal range in southeastern Australia but seems to be most abundant in alpine heath and in open forest communities with dense understorey of ferns or shrubs. In Kosciuszko National Park, Happold (1989:222) found this species to extend to $2000 \mathrm{~m}$ asl and to occupy 'stream valleys and moist heathlands ... with abundant leaf-litter and soft soil'. Sminthopsis leucopus is known from numerous extant populations in Tasmania and around the coastal margin of the Southeastern Highlands. However, co-occurrence at relatively high abundance with $S$. murina, such as in Unit III of Y259, is unknown among modern populations, again suggesting a potentially high-productivity environment. However such environmental conditions are presumably mirrored at many modern sites, so why the two species co-occur in this site remains enigmatic.

It is difficult to interpret the apparent change in local dominance of Perameles nasuta in lower spits to Isoodon obesulus in higher levels because we have no knowledge of the ecology of inland populations of $I$. obesulus. Furthermore, although no $P$. nasuta was found in higher levels of Y259, the species is still present in the region, although uncommon. The absence of $P$. nasuta from higher spits is presumably partly an artefact of small sample size, but the relative dominance of $I$. obesulus is borne out at other Yarrangobilly sites and suggests an increased coverage of heath communities through the later Holocene. A similar indicator of climate may be the reduction in relative abundance of Pseudomys oralis from lower to higher spits and the relative increase in $P$. fumeus. All these species are capable of inhabiting a wide range 
of habitats, but $P$. fumeus and I. obesulus tend to be relatively more abundant in drier heath components of forest habitats than their counterparts (Claridge 1988; Ford et al. 2003).

Pseudomys higginsi is present but scarce in Unit III (and II), and considerably more abundant in Spits $S$ and 1 of Unit I. As noted above, the mainland population of this species probably favoured relatively cooler conditions.

Cercartetus nanus is also significantly less abundant in Unit III than in Units I-II. This species occupies a wide range of habitats in southeastern Australia, from rainforest to coastal heath, but is most abundant in habitats that provide abundant nectar, such as coastal Banksia woodland (Bowen and Goldingay 2000). It was not listed by Happold (1989) as a member of the Southern Alps mammal fauna, but it has been recorded as a rare animal in all local bioregions, including the Australian Alps. The shrubby components, such as stands of Banksia, that tend to favour C. nanus are present, though scattered, in the area surrounding Y259.

In summary, the mammal assemblage from Unit III of Y259 suggests a local environment that included significant areas of wet sclerophyll forest and probably featured higher overall productivity than present-day communities. Indicators of understorey structure and composition suggest a mosaic including both moist, dense patches, supporting populations of such taxa as Antechinus swainsonii, and more open vegetation, supporting high local populations of Perameles nasuta, Pseudomys novaehollandiae and Sminthopsis spp.

\section{Aboriginal occupation of the Southeastern Highlands}

The small collection of stone artefacts and archaeological faunal remains from Unit III of the Y259 deposit, dating to the period 9700-9120 cal. BP, more than doubles the previously known 4500-year history of occupation above $1000 \mathrm{~m}$ asl in the southeast Australian Alps. The small archaeological assemblage recovered to date provides only scant clues as to what might have drawn people on to the Yarrangobilly Plateau during the early Holocene. The component of the faunal assemblage that can be attributed to human activity suggests fairly opportunistic hunting activity, without the strong focus seen in the LGM assemblages from southwest Tasmania. While the assemblage does include the remains of red-necked wallabies, the preferred prey species of late-Pleistocene Tasmanians, there are approximately equal numbers of other prey taxa, including rock wallabies, possums and a bandicoot. This broader range of prey items is probably due in part to the more diverse local fauna compared with that available to the Tasmanian hunters. Nevertheless, some prey selectivity is also apparent in the Y259 assemblage, with a clear preference for medium-sized to large mammals over the numerous small vertebrates that occurred locally around the site.

At present, it is unclear whether use of the site continued through the period of deposition of Unit II. No artefacts were recovered from Spit 5 of Unit II and only two bones show evidence of burning, and in neither case is it intense. However, the fauna from this period does contain a higher proportion of medium-sized mammals than the samples from Unit I. Further insight into this question may come from analysis of the sample from Spit 6.

There is no evidence whatsoever for human activity at the site during deposition of Unit I. The large faunal assemblage contains relatively few medium-sized mammals, displays no evidence of burning, and no stone artefacts were recovered within the excavated area or noted across the wider surface of the deposit. If people visited the site at all during the recent past, they left little or no record of their activities. Why this should be so is not clear. The cave provides an obvious shelter from both cold and hot temperatures and at least in recent years, it clearly harbours seasonal aggregations of bogong moths, a significant food resource for local aboriginal people during the early historic period.

The site of Birrigai, located at $730 \mathrm{~m}$ asl and approximately $55 \mathrm{~km}$ by air to the northeast of Yarrangobilly, provides evidence of a human presence in the wider region back at least to 25,000 years ago (Flood et al. 1987), at which time the world was firmly in the grip of the 
Last Glacial Maximum (Barrows et al. 2002). Birrigai at that time was very likely above the local tree line and surrounded by grass-covered slopes affected by periglacial processes. People continued to visit Birrigai on an occasional basis through the remainder of the Pleistocene and into the Holocene, with no obvious change to indicate any major human response to the return of woodland to the valley or to the warmer conditions of the Holocene Optimum. The past 3000 years saw more frequent visitation to Birrigai. Unfortunately, the Birrigai deposit provides a poor environment for organic preservation and there is little direct evidence of economic activities through most of its long history of occupation.

Better organic preservation, including both animal and plant remains, is present in the inner chamber of Cloggs Cave, situated at $76 \mathrm{~m}$ asl on the southern flanks of the southeast Australian Alps. As in Y259, the faunal remains are clearly of mixed origin, including some derived from human activity and others introduced by owls and other predators. Although these components could not be distinguished with any certainty, Flood (1987:267) does note that 'the bone nearer the centre of the cave includes more large mammals such as macropodids, and is more likely to represent human dietary remains'. Judging from the relatively small quantities of discarded stone artefacts and larger mammal bone, Cloggs Cave was visited on an occasional basis only, between c. 21,000 cal. BP and c. $9800 \mathrm{cal}$. BP. After this date, no fires were lit in the inner chamber of Cloggs Cave and sedimentation slowed dramatically. Flood (1980:268) interpreted this as a possible response to the post-glacial amelioration of climate, perhaps encouraging a 'move out of the cave into the open'. Within the past 1000 years or so, people made limited use of the outer chamber of Cloggs Cave, but did not reoccupy its inner chamber.

It is interesting to note that the last definite evidence of human activity in Y259 coincides closely in time with abandonment of the Cloggs Cave inner chamber, and more generally, with the regional expansion of wet sclerophyll forest in response to the Holocene Optimum. On a regional scale, we also note with interest that the earliest evidence for reoccupation of the southeast Australian Alps, at around 4500 years ago, is broadly coincident with the termination of the Pomaderris Interval, presumably signalling the regional decline of wetter forest communities. If these observations gain further support, we might begin to ponder whether the history of human use of the southeast Australian Alps through the Holocene was driven in large part by the relative ease of access through vegetation communities changing in response to global climatic shifts.

Further excavation in Y259 clearly represents a high priority for archaeological research in the southeast Australian Alps. If the archaeological deposit in Y259 is deeper, continuing below the level of the limestone rubble, then it seems certain to extend back into the terminal Pleistocene. On the other hand, if the full sequence has already been documented for Y259, there is a strong case for recovering a larger sample of cultural remains representing the initial period of the Holocene Optimum and to clarify the timing and extent of any subsequent human activity.

\section{Conclusion}

Cave Y259 contains an important faunal sequence and significant cultural material that together provide a fascinating window into the time of the Holocene Optimum in the Southern Australian Highlands. People visited the cave on several occasions over the time interval 9700-9120 cal. BP, moving through a landscape that contained significant areas of wet sclerophyll forest, and left behind stone artefacts and the burnt and fragmented remains of their mammalian prey. After that time, the cave appears to have been unoccupied or visited very infrequently. However, many generations of owls continued to use the cave, leaving behind a rich record of local mammalian communities. More detailed analysis of the entire 
excavated sequence will shed light on the time of regional extinction of several species of key interest, including Gymnobelideus leadbeateri and Pseudomys higginsi.

\section{Acknowledgements}

We thank Rohan Bilney and Angela Frost for assistance with cave excavations at Yarrangobilly and cave managers Peter Bell and George Bradford for their interest and co-operation throughout the project. Angela Frost also assisted with sorting and identifications, and prepared the site diagrams. Aplin very belatedly thanks Geoff Hope for first suggesting that he study faunal remains as a way of keeping him out of even greater mischief. Excavation was carried out under a regional consent issued on September 262005 from NSW National Parks and Wildlife Service, South West Slopes Region, Tumut.

\section{References}

Alley, R.B. and P.U. Clark 1999. The deglaciation of the Northern Hemisphere: A global perspective. Annual Review of Earth and Planetary Science 27:149-182.

Andres, M.S., S.M. Bernasconi, J.A. McKenzie and U. Röhl 2003. Southern Ocean deglacial record supports global Younger Dryas. Earth and Planetary Science Letters 216:515-524.

Archer, M. 1981. Results of the Archbold Expeditions. No. 104. Systematic revision of the marsupial dasyurid genus Sminthopsis Thomas. Bulletin of the American Museum of Natural History 168:61-224.

Asmussen, B. 2009. Intention or incidental thermal alteration? Analysing site occupation through burnt bone. Journal of Archaeological Science 36:528-536.

Barrows, T.T., J. O. Stone, L.K. Fifield and R.G. Cresswell 2001. Late Pleistocene glaciation of the Kosciuszko Massif, Snowy Mountains, Australia. Quaternary Research 55:179-189.

Barrows, T.T., J.O. Stone, L.K. Fifield and R.G. Cresswell 2002. The timing of the Last Glacial Maximum in Australia. Quaternary Science Reviews 21:159-173.

Bennett, A.F. 1993. Microhabitat use by the long-nosed potoroo, Potorous tridactylus, and other small mammals in remnant forest vegetation of south-western Victoria. Wildlife Research 20:267-285.

Bennett, S., R. Brereton, I. Mansergh, S. Berwick, K. Sandiford and C. Wellington 1991. Enhanced greenhouse climate change and its potential effect on selected Victorian fauna. Arthur Rylah Institute Tech. Rep. No. 123. Department of Conservation and Environment, Victoria.

Bilney, R., R. Cooke and J. White 2006. Change in the diet of sooty owls (Tyto tenebricosa) since European settlement: from terrestrial to arboreal prey and increased overlap with powerful owls. Wildlife Research 33:17-24.

Bowen, M. and R. Goldingay 2000. Distribution and status of the eastern pygmy possum (Cercartetus nanus) in New South Wales. Australian Mammalogy 21:153-164.

Bowler, J.M. 1981. Australian Salt Lakes. Hydrobiologia 82:431-444.

Breed, W. and F. Ford 2007. Native Mice and Rats. Collingwood: CSIRO Publishing.

Bronk Ramsey, C. 2001. Development of the radiocarbon calibration program OxCal. Radiocarbon 43:355-363.

Broome, L.S., 2001. Intersite differences in population demography of Mountain Pygmypossums Burramys parvus Broom (1987-1998): Implications for metapopulation conservation in Kosciuszko National Park. Biological Conservation 102:309-323. 
Chivas, A.R., P. De Deckker, J. A. Cali, A. Chapman, E. Kiss and J.M.G. Shelley 1993. Coupled stable-isotope and trace-element measurements of lacustrine carbonates as palaeoclimatic indicators. American Geophysical Monographs 78:113-121.

Claridge, A.W. 1988. Diet and ecology of the Southern Brown and Long-nosed Bandicoots in South-eastern New South Wales. Honours Thesis, Department of Forestry, the Australian National University, Canberra.

Colhoun, E.A. and G. van de Geer 1986. Holocene to middle last glaciation vegetation history at Tullabardine Dam, western Tasmania. Proceedings Royal Society of London B229:177-207.

Colhoun, E.A., G. van de Geer, S.J. Fitzsimons and L.E. Heusser 1994. Terrestrial and marine records of the last glaciation from western Tasmania: Do they agree? Quaternary Science Reviews 13:293-300

Cosgrove, R. 1999. Forty-two degrees south: the archaeology of late Pleistocene Tasmania. Journal of World Prehistory 13:357-402.

Cosgrove, R., J. Allen and B. Marshall 1990. Palaeo-ecology and Pleistocene human occupation in south central Tasmania. Antiquity 64:59-78.

D’Costa D.M., P. Edney, A.P. Kershaw and P. De Deckker 1989. Late Quaternary palaeoecology of Tower Hill, Victoria, Australia. Journal of Biogeography 16:461-482.

Dickman, C. and M.D. Stoddart 2008. Perameles nasuta. In S. Van Dyke and R. Strahan (eds), Mammals of Australia, pp189-190. Sydney: Reed Books.

Dodson, J.R., T. De Salis, C.A. Myers and A.J. Sharp 1994. A Thousand Years of Environmental Change and Human Impact in the Alpine Zone at Mt. Kosciuszko, New South Wales. Australian Geographer 25:77-87.

Drummond, D.C. 1963. Bone deposits in caves. Journal of the Sydney University Speleological Society 6:29-42.

Flood, J. 1980. The Moth Hunters. Aboriginal Prehistory of the Australian Alps. Canberra: Australian Institute of Aboriginal Studies.

Flood, J., B. David, J. Magee and B. English 1987. Birrigai: a Pleistocene site in the southeastern highlands. Archaeology in Oceania 22:9-26.

Foley, J.A., J.E. Kutzbach, M.T. Coe and S. Levis 1994. Feedbacks between climate and boreal forests during the Holocene epoch. Nature 371:52-54.

Ford, F. 1998. The smoky mouse in the Nullica region and Kosciuszko National Park: winter and spring 1998. Report, New South Wales National Parks and Wildlife Service, Queanbeyan.

Ford, F., A. Cockburn and L. Broome 2003. Habitat preference, diet and demography of the smoky mouse, Pseudomys fumeus (Rodentia: Muridae), in south-eastern New South Wales. Wildlife Research 24:417-432.

Ford et al. In prep.

Fox, B.J. 2008. Sminthopsis murina. In S. Van Dyke and R. Strahan (eds), Mammals of Australia, pp152-154. Sydney: Reed Books.

Fox, B.J. and M.D. Fox. 1978. Recolonisation of coastal heath by Pseudomys novaehollandiae. Australian Journal of Ecology 3:447-465.

Fox, B.J., D.G. Read, E. Jeffereys and J. Luo 1994. Diet of the Hastings River mouse (Pseudomys oralis). Wildlife Research 21:491-505.

Green, K. and W.S. Osborne 2003. The distribution and status of the Broad-toothed Rat Mastacomys fuscus (Rodentia: Muridae) in NSW and the ACT. Australian Zoologist 32:229-237.

Green, D., G. Singh, H. Polach, D. Moss, J. Banks and E.A. Geissler 1988. A fine-resolution palaeoecology and palaeoclimatology from southeastern Australia, Journal of Ecology 76:790-806.

Grootes, P.M., M. Stuiver, J.W.C. White, S. Johnsen and J. Jouzel 1993. Comparison of oxygen isotope records from GISP2 and GRIP Greenland ice cores. Nature 366:552-554. 
Haering, R. and B.J. Fox 1997. Habitat use by sympatric populations of Pseudomys novaehollandiae and Mus domesticus in coastal heathland. Australian Journal of Ecology 22:69-87.

Hall, L.S. 1975. A recent bone deposit at marble arch, N.S.W. Proceedings of the $10^{\text {th }}$ biennial conference of the Australian Speleological Federation, pp35-44.

Happold, D.C.D. 1989. Small mammals of the Australian Alps. In R. Good (ed.), The scientific significance of the Australian Alps, pp221-239. Canberra: Australian Alps National Parks Liaison Committee.

Hope, G. 2003. The mountain mires of southern New South Wales and The Australian Capital Territory: their history and future. In J. Mackay \& Associates (eds), Celebrating Mountains. Proceedings of an International Year of Mountains Conference, pp67-79. Canberra: Australian Alps Liaison Committee.

Hope, G., A.P. Kershaw, S. Van der Kaars, S. Xiangjun, P-M. Liew, L.E. Heusser, H. Takahara, M. McGlone, N. Miyoshi and P.T. Moss 2004. History of vegetation and habitat change in the Austral-Asian region. Quaternary International 118-119:103-26.

Hope, J. H. 1976. Quaternary fossil mammal localities in Southeastern New South Wales and Eastern Victoria. Unpublished manuscript.

Jerry, D.R., T.A. Dow, M.S. Elphinstone and P.R. Baverstock 1998. Historical and contemporary maternal population structuring in the endangered Hastings River mouse (Pseudomys oralis). Conservation Biology 12:1017-1022.

Jones, R. 1995. Tasmanian archaeology: Establishing the sequences. Annual Review of Archaeology 24:423-446.

Kamminga, J. 1992. Aboriginal settlement and prehistory of the Snowy Mountains. In B. Scougall (ed.), Cultural Heritage of the Australian Alps, pp101-124. Canberra: Australian Alps National Parks Liaison Committee.

Kamminga, J. 1995. Prehistory of the Snowy Mountains, southeastern Australia. In E. Johnson (ed.), Ancient peoples and landscapes, pp153-171. Lubbock: Museum of Texas Tech University.

Kavanagh, R.P. and M. Murray 1996. Home range, habitat and behaviour of the Masked Owl Tyto novaehollandiae near Newcastle, New South Wales. Emu 96:250-257.

Kershaw, A.P. and K.M. Strickland 1989. The development of alpine vegetation on the Australian mainland. In R. Good (ed.), The scientific significance of the Australian Alps, pp113-126. Canberra: Australian Alps National Parks Liaison Committee.

Kershaw, A.P., G.M. McKenzie, N. Porch, R.G. Roberts, J. Brown, H. Heijnis, M.L. Orr, G. Jacobsen and P.R. Newall 2007. A high-resolution record of vegetation and climate through the last glacial cycle from Caledonia Fen, southeastern highlands of Australia. Journal of Quaternary Science 22:481-500.

Kiernan, K., R. and D. Ranson 1983. New evidence from Fraser Cave for glacial age man in south-west Tasmania. Nature 301:28-32.

Kusmer, K.D. 1990. Taphonomy of owl pellet deposition. 64:629-637.

Ladd, P.G. 1979. Past and present vegetation on the Delegate River in the highlands of eastern Victoria. II. Vegetation and climatic history from 12,000 B.P. to present. Australian Journal of Botany 27:185-202.

Lock, M.L. and B.A. Wilson. 1999. The distribution of the New Holland mouse (Psendomys novaehollandiae) with respect to vegetation near Anglesea, Victoria. Wildlife Research 26:565-577.

Lourandos, H. 1997. Continent of hunter-gatherers: new perspectives in Australian prehistory. Cambridge: Cambridge University Press.

Lundie-Jenkins, G. 1993. The diet of the Sooty owl Tyto tenebricosa in the Blue Mountains, N.S.W. Emu 93:124-127. 
Lunney, D., M. O'Connell, J. Sanders and S. Forbes 1989. Habitat of the white-footed dunnart Sminthopsis leucopus (Gray) (Dasyuridae: Marsupialia) in a logged, burnt forest near Bega, New South Wales. Austral Ecology 14: 335-344.

McKenzie, G.M. 1997. The late Quaternary vegetation history of the south-central highlands of Victoria, Australia. I. Sites above 900 m. Australian Journal of Ecology 22:19-36.

McKenzie, G.M. 2002. The late Quaternary vegetation history of the south-central highlands of Victoria, Australia. II. Sites below 900 m. Austral Ecology 27:32-54.

Macphail, M.K. and G.S. Hope 1985. Late Holocene mire development in montane southeastern Australia: a sensitive climatic indicator. Search 15:344-349

Mansergh, I., B. Baxter, D. Scotts, T. Brady and D. Jolley 1990. Diet of Burramys parvus (Marsupialia: Burramyidae) and other small mammals in the alpine environment at $\mathrm{Mt}$ Higginbotham, Victoria. Australian Mammalogy 13:167-77.

Martin, A.R.H. 1999. Pollen analysis of Digger's Creek Bog, Kosciuszko National Park: vegetation history and tree-line change. Australian Journal of Botany 47:725-744.

Mooney, S.D., J.R. Watson and J.R. Dodson 1997. Late Holocene environmental change in an upper montane area of the Snowy Mountains, NSW. Australian Geographer 28:185-200.

Morgan, V., M. Delmotte, T. van Ommen, J. Jouze, J. Chappellaz, S. Woon, V. MassonDelmotte and D. Raynaud 2002. Relative timing of deglacial events in Antarctica and Greenland. Science 297:1862-1864.

Morton, S.R., M. Happold, A.K. Lee and R.E. Macmillen 1977. The diet of the Barn owl, Tyto alba, in South-western Queensland. Australian Wildlife Research 4:91-97.

Mulvaney, J. and J. Kamminga 1999. Prehistory of Australia. Sydney: Allen and Unwin.

Nicholson, R.A. 1993. A morphological investigation of burnt animal bone and an evaluation of its utility in archaeology. Journal of Archaeological Science 20:411-428.

Peteet, D. 1995. Global Younger Dryas. Quaternary International 28:93-104.

Read, D.G. and T.D. Tweedie 1996. Floristics of habitats of Pseudomys oralis (Rodentia: Muridae). Wildlife Research 23:485-493.

Ride, W.D.L., G. Taylor, P.H. Walker and A.C. Davis 1989. Zoological history of the Australian Alps - the mammal fossil-bearing deposits of the Monaro. In R. Good (ed.), The scientific significance of the Australian Alps, pp79-110. Canberra: Australian Alps National Parks Liaison Committee.

Seebeck, J.H. and P.G. Johnston 1980. Potorous longipes (Marsupialia: Macropodidae); a new species from eastern Victoria. Australian Journal of Zoology. 28:119-34.

Stager, J.C., B. Cumming and L. Meeker 1997. A high-resolution 11,400-yr diatom record from Lake Victoria, East Africa. Quaternary Research 47:81-89.

Smith, A.P. and D.G. Quin 1996. Microhabitat requirements of the Hastings River mouse (Pseudomys oralis) (Rodentia: Muridae). New South Wales National Parks and Wildlife Service.

Stanley, S. and P. De Deckker 2002. A Holocene record of allochthonous, aeolian mineral grains in an Australian alpine lake; implications for the history of climate change in southeastern Australia. Journal of Paleolimnology 27:207-219.

Stiner, M.C., S.L. Kuhn, S. Weiner and O. Bar-Josef 1995. Differential burning, recrystallization, and fragmentation of archaeological bone. Journal of Archaeological Science 22:223-237.

Stoddart, D.M. and G. Challis 1991. The habitat and field biology of the long-tailed mouse (Pseudomys higginsi). Tasmanian Forest Research Council. Research Report No. 6.

Thackway R. and I.D. Creswell 1995. An Interim Biogeographic Regionalisation for Australia: a framework for establishing the national system of reserves, Version 4.0. Canberra: Australian Nature Conservation Agency. 
Turney, C.S.M., S. Haberle, D. Fink, P. Kershaw, M. Barbetti, T.T. Barrows, M. Black, T.J. Cohen, T. Corrège, P.P. Hesse, Q. Hua, R. Johnston, V. Morgan, P. Moss, G. Nanson, T. Vanommen, S. Rule, N.J. Williams, J.-X. Zhao, D. D’Costa, Y.-X. Feng, M. Gagan, S. Mooney and Q. Xia 2006. Integration of ice-core, marine and terrestrial records for the Australian Last Glacial Maximum and Termination: a contribution from the OZ INTIMATE group. Journal of Quaternary Science 21:751-761.

Wakefield, N.A. 1972a. Studies in Australian Muridae: review of Mastacomys fuscus, and description of a new subspecies of Pseudomys higginsi. Memoirs of the National Museum of Victoria 33:15-31.

Wakefield, N.A. 1972b. Palaeoecology of fossil mammal assemblages from some Australian Caves. Proceedings of the Royal Society of Victoria 85:1-26.

Wallis, R.L. 1992. The broad-toothed rat (Mastacomys fuscus) in Dandenong Ranges National Park - a colony located in regenerating forest. Victorian Naturalist 109:177-178.

Wang, Y.J., H. Cheng, R.L. Edwards, Z.S. An, J.Y. Wu, C.-C. Shen and J.A. Dorale 2001. A high-resolution absolute-dated late Pleistocene monsoon record Hulu Cave, China. Science 294:2345-2348.

Zhou, W., W. Yu, A.J.T. Jull, G. Burr, J.Y. Xiao, X. Lu and F. Xian 2004. High-resolution evidence form southern China of an early Holocene optimum and a mid-Holocene dry event during the last 18,000 years. Quaternary Research 62:39-48. 